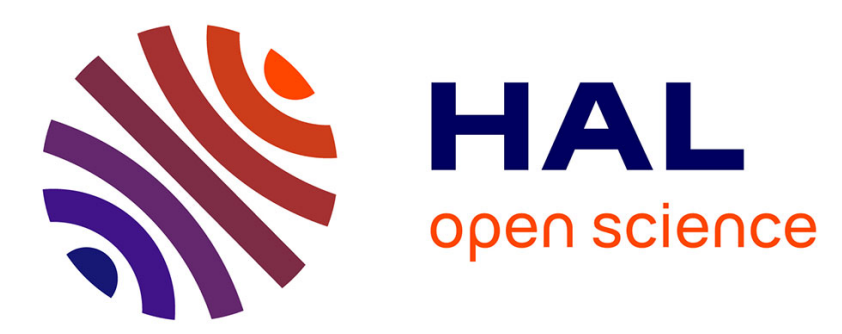

\title{
New damsel-dragonflies with "calopterygid"-like wing shape from the Middle Jurassic of China (Odonata: Isophlebioidea: Campterophlebiidae)
}

\author{
Diying Huang, Chenyang Cai, André Nel
}

\section{- To cite this version:}

Diying Huang, Chenyang Cai, André Nel. New damsel-dragonflies with "calopterygid"-like wing shape from the Middle Jurassic of China (Odonata: Isophlebioidea: Campterophlebiidae). Geobios, 2018, 10.1016/j.geobios.2018.04.003 . hal-01787087

\section{HAL Id: hal-01787087 \\ https://hal.sorbonne-universite.fr/hal-01787087}

Submitted on 7 May 2018

HAL is a multi-disciplinary open access archive for the deposit and dissemination of scientific research documents, whether they are published or not. The documents may come from teaching and research institutions in France or abroad, or from public or private research centers.
L'archive ouverte pluridisciplinaire HAL, est destinée au dépôt et à la diffusion de documents scientifiques de niveau recherche, publiés ou non, émanant des établissements d'enseignement et de recherche français ou étrangers, des laboratoires publics ou privés. 
New damsel-dragonflies with "calopterygid"-like wing shape from the Middle Jurassic of China (Odonata: Isophlebioidea: Campterophlebiidae)

Diying Huang ${ }^{\mathrm{a}}$, Chenyang Cai ${ }^{\mathrm{a}}$, André $\mathrm{Nel}^{\mathrm{c}}$

a State Key Laboratory of Palaeobiology and Stratigraphy, Nanjing Institute of Geology and Palaeontology, Chinese Academy of Sciences, Nanjing 210008, People’s Republic of China (dyhuang@nigpas.ac.cn; cycai@nigpas.ac.cn)

${ }^{b}$ Institut de Systématique, Évolution, Biodiversité, ISYEB - UMR 7205 - CNRS, MNHN, UPMC, EPHE, Muséum national d'Histoire naturelle, Sorbonne Universités, 57 rue Cuvier, CP 50, Entomologie F-75005, Paris, France (anel@mnhn.fr)

\begin{abstract}
The new damsel-dragonflies Zygokaratawia incompleta nov. sp. and Parazygokaratawia azari nov. gen., nov. sp., closely related to the campterophlebiid genus Zygokaratawia, are described from the Middle Jurassic locality of the Daohugou and Chentaizi villages respectively in Ningcheng County, Inner Mongolia, NE China. Parazygokaratawia and Zygokaratawia share a narrowly reduced cubito-anal area, unique synapomorphy in the Isophlebioptera. Campterophlebiids with this character are only known from the Daohugou biota.
\end{abstract}

Keywords:

Insecta; Odonata; Campterophlebiidae; nov. gen., nov. sp.; Daohugou biota

\title{
1. Introduction
}


The insect order Odonata is divided into two main clades Zygoptera (damselflies) and Epiproctophora, a clade that comprises several extinct clades and the living Epiophlebiidae (damsel-dragonflies) and the Anisoptera (true dragonflies) (Bechly, 1996). The Isophlebioidea is one of the most diverse clades of Mesozoic damsel-dragonflies. Their oldest-known representatives are found in Late Triassic-Early Jurassic strata and the youngest in the Late Cretaceous. The family Campterophlebiidae is the largest family of this clade (Nel et al., 1993; Bechly, 1996). Ten campterophlebiid genera are currently known from the Middle JurassicLower Cretaceous of north China (see summary in Zheng et al., 2016; 2017). Among them, one of the more curious is the genus Zygokaratawia Nel et al., 2008, characterized by very narrow hindwings with narrow cubito-anal area. This particular shape of wings is looking like that of a modern Calopterygoidea. Here we describe two new taxa with similar wing shapes from the same locality of Daohugou in Inner Mongolia.

\section{Material and methods}

The type specimens were prepared with a steel needle under microscope. Photographs were taken using Nikon $5 \mathrm{~d} 2$ camera. The type specimen of Zygokaratawia incompleta is preserved in a whitish tuffaceous shale associated with lots of conchostracans of the genus Euestheria, indicating that it comes from the Dadaogou Layer near the Daohugou Village where the outcrops are now covered by the Museum. It comes from an upper layer of the Daohugou beds. The type specimen of Parazygokaratawia azari is preserved in a grayish tuffaceous shale associated with lots of cladocerans, indicating that it comes from the top most layers of the Daohugou beds near the Chengtaizi Village (Fig. 1).

The nomenclature of the odonatan wing venation used in this paper is based on the interpretations of Riek \& Kukalová-Peck (1984), as modified by Nel et al. (1993) and Bechly (1996). The higher classification of fossil Odonatoptera, as well as family and generic 
characters followed in the present work, are based on the phylogenetic system proposed by Bechly (1996). Wing abbreviations are as follows: AA analis anterior; AP, analis posterior; Arc, arculus; Ax, primary antenodal crossvein; CuA cubitus anterior; $\mathrm{CuP}$, cubitus posterior; $\mathrm{d}$ discoidal cell; IRx intercalary radial veins; MA median anterior; MP median posterior; N nodus; Pt pterostigma; RA radius anterior; RP radius posterior; sd subdiscoidal cell.

\section{Systematic palaeontology}

Order Odonata Fabricius, 1793

Superfamily Isophlebioidea Handlirsch, 1906

Family Campterophlebiidae Handlirsch, 1920

Remark. The list of campterophlebiid genera is available in the internet site Fossilworks. http://fossilworks.org/bridge.pl?a=taxonInfo\&taxon_no=176742.

Genus Zygokaratawia Nel et al., 2008

Type species. Zygokaratawia reni Nel et al., 2008, other species. Zygokaratawia incompleta nov. sp.

Zygokaratawia incompleta nov. sp.

Fig. 2

Derivation of name: named after the incomplete state of preservation of the type, as only hindwings are preserved.

Holotype: Specimen NIGP167276 (a thorax with two hindwings and the two-third of the abdomen attached), stored at Nanjing Institute of Geology and Palaeontology, Chinese Academy of Sciences, China.

Type locality: Near the Daohugou Village, Wuhua Township, Ningcheng County, Chifeng City, Inner Mongolia, NE China. 
Type horizon: Lowest Upper Jurassic, Haifanggou Formation (ca. 162-163 Ma); Inner Mongolia, NE China.

Diagnosis: Hindwing pterostigma strongly basally recessed, with ten cells between C and RA distal of pterostigma; 12 postnodals; 12 crossveins in antesubnodal area; a strongly oblique crossvein between MAa and base of RP3/4; 10 crossveins in Bqr space.

Description: Thorax large, $4.4 \mathrm{~mm}$ wide, $5.2 \mathrm{~mm}$ long, but compressed. Hind wing hyaline, $33.3 \mathrm{~mm}$ long, $7.5 \mathrm{~mm}$ wide, widest part at level of nodus; distance between base and arculus $4.4 \mathrm{~mm}$, arculus and nodus $10.0 \mathrm{~mm}$, nodus and pterostigma $11.2 \mathrm{~mm}$, pterostigma and apex $5.3 \mathrm{~mm}$; a rather long petiole, $2.4 \mathrm{~mm}$ long, $1.4 \mathrm{~mm}$ wide; anal area very narrow, $3.1 \mathrm{~mm}$ long, $0.7 \mathrm{~mm}$ wide, nearly triangular in shape, with one row of irregular cells between AA and AP; no anal angle but AP weakly curved (female specimen); no membranule; AA distally strongly bent towards posterior wing margin and nearly parallel with $\mathrm{MP}+\mathrm{CuA}$, distally fused with $\mathrm{CuAb}$; median and submedian areas free; curved vein $\mathrm{CuP}$ just basal of $\mathrm{Ax} 1$; subdiscoidal area transverse, poste has hindwings very similarriorly closed, short and broad, with one crossvein, $1.4 \mathrm{~mm}$ long, $0.9 \mathrm{~mm}$ wide; discoidal cell basally closed, $0.7 \mathrm{~mm}$ long, $0.5 \mathrm{~mm}$ wide, free of crossveins, length of proximal side $0.4 \mathrm{~mm}$; RP+MA separates at approximately a right angle from RA and strongly curved in arculus; RP separated from MA $0.3 \mathrm{~mm}$ distally; MA basally strong and divided into MAa and MAb $0.7 \mathrm{~mm}$ distally; MAb short, $0.8 \mathrm{~mm}$ long, aligned with distal free part of $\mathrm{CuA}$; $\mathrm{MP}+\mathrm{CuA}$ separated into $\mathrm{MP}$ and $\mathrm{CuA}$ at distal end of $\mathrm{MAb}$; distal free part of $\mathrm{CuA}$ strong, separating from MP $5.4 \mathrm{~mm}$ from wing base and extends towards posterior wing margin for $0.5 \mathrm{~mm}$; $\mathrm{CuA}$ distally divided into $\mathrm{CuAa}$ and $\mathrm{CuAb}, \mathrm{CuAb}$ short, $0.4 \mathrm{~mm}$ long, extending towards basal wing margin and meeting main branch of $\mathrm{AA}$; $\mathrm{CuAa}$ basally more or less parallel to posterior wing margin with only one row of cells between them; CuAa short, ending on posterior wing margin about $6.7 \mathrm{~mm}$ from its base, well before nodus level; area between $\mathrm{CuAa}$ and MP with one row of cells, $1.4 \mathrm{~mm}$ wide; distal of end of $\mathrm{CuAa}$, area between 
MP and posterior wing margin very long and broad; MP nearly straight, reaching posterior margin well distal of nodus level, ca $22.0 \mathrm{~mm}$ from wing base; MAa parallel with MP, nearly straight in its basal part, postdiscoidal area $0.9 \mathrm{~mm}$ wide, with one row of cells; Ax1 $0.35 \mathrm{~mm}$ basal of arculus, nearly perpendicular to ScP; Ax2 $2.1 \mathrm{~mm}$ distal of arculus, oblique; no secondary antenodal crossveins between $\mathrm{C}$ and $\mathrm{ScP}$, but seven secondary antenodal cross-veins between ScP and RA distal of Ax2; 12 cross-veins in area between RA and RP, between arculus and nodus; base of RP3/4 $0.35 \mathrm{~mm}$ distal of arculus, closer to arculus than to nodus; base of IR2 close to that of RP3/4, $1.5 \mathrm{~mm}$ distally; no antefurcal crossvein in space between RP and MA basal of midfork (base of RP3/4), except for a very oblique crossvein between MAa and base of RP3/4; 12 postnodal cross-veins between C and RA; 11 postsubnodal cross-veins between RA and RP1 not aligned with postnodals; pterostigmal brace rudimentary, not oblique and not well-aligned with basal side of pterostigma; four crossveins below pterostigma; pterostigma sclerotized, $4.4 \mathrm{~mm}$ long, $0.65 \mathrm{~mm}$ wide; pterostigma rather basally recessed with 10 cells between $\mathrm{C}$ and RA distal of it; RP2 aligned with subnodus; 10 crossveins in Bqr space between RP, RP2, IR2 and first oblique vein "O"; oblique vein “O” $2.3 \mathrm{~mm}$ and four cells distal of base of RP2; RP2 nearly straight; base of IR1 five cells distal of base of RP2; IR1 basally weakly zigzagging but distally nearly straight, more or less parallel to RP1; area between MA and RP3/4 much wider distally, with 17 rows of cells along posterior wing margin; area between RP3/4 and IR2 as broad basally as distally, with basally one row of cells and two distally; area between IR2 and RP2 with one row of cells and distally seven rows near posterior wing margin; area between RP2 and IR1 progressively widened, with one zigzagging intercalary longitudinal vein and 2-3 rows of cells between them; area between IR1 and RP1 not distally widened, with 3-4 rows of cells between them.

Abdomen with only seven basal segments preserved, $2.1 \mathrm{~mm}$ wide, no secondary male genital apparatus on second segment. 
Remarks: Zygokaratawia incompleta nov. sp. has hindwings very similar to those of the campterophlebiid Zygokaratawia reni Nel et al., 2008, also from the same outcrop (Nel et al., 2008). The differences between the two fossils are as follows: pterostigma more basally recessed in Z. incompleta than in Z. reni, with ten cells between $\mathrm{C}$ and RA distally in $Z$. incompleta against only four in Z. reni; 12 postnodals for Z. incompleta instead of ten for Z. reni; 12 crossveins in antesubnodal area in $Z$. incompleta instead of five in $Z$. reni; a strongly oblique crossvein between MAa and base of RP3/4 in Z. incompleta, absent in Z. reni; 10 crossveins in Bqr space of Z. incompleta instead of five in Z. reni.

Among the campterophlebiids with a venation relatively similar to that of Zygokaratawia, Z. incompleta differs from Sarytashia Pritykina, 1970 in RP2 without a pronounced distal curve and different shape of secondary veins between IR1 and RP1. Adelophlebia Pritykina, 1980 is known by the forewing base but it differs from Zygokaratawia incompleta in the presence of two rows of cells in postdiscoidal area (Pritykina, 1970, 1980; Nel et al., 1993). Z. incompleta differs from Ctenogampsophlebia Petrulevičius et al., 2011 in the shorter discoidal cell, presence of well-defined longitudinal secondary vein between IR1 and RP1, longer pterostigma, and broader area between CuAa and MP (Petrulevičius et al., 2011). For the comparison with Parazygokaratawia nov. gen., see below.

Genus Parazygokaratawia nov. gen.

Derivation of name: A combination of 'para' and the genus Zygokaratawia and for the strong similarity with this genus.

Type species: Parazygokaratawia azari nov. sp.

Diagnosis: Wing venation characters only. Hindwing subdiscoidal space small and posteriorly closed; cubito-anal and anal areas very narrow in both fore and hind wings; a long basal part to $\mathrm{CuA}$ before its branches; area between MP and $\mathrm{CuA}$ as broad as postdiscoidal area, which is 
distally constricted; MP straight; MAa zigzags and becomes much weakened distally; CuAa short; pterostigma not basally recessed; area between RP3/4 and IR2 widened along posterior wing margin; base of RP2 not aligned with subnodus; IR1 basally straight; only one row of cells between IR1 and RP1 between its base and pterostigma; Ax2 perpendicular to ScP in hindwing.

Parazygokaratawia azari nov. sp.

Figs 3-4

Derivation of name: Named after our friend and colleague, Prof. Dany Azar.

Holotype: Specimen NIGP167528 (imprint), Nanjing Institute of Geology and Palaeontology, Chinese Academy of Sciences, China.

Type locality: Near the Chentaizi Village, Wuhua Township, Ningcheng County, Chifeng City, Inner Mongolia, NE China.

Type horizon: Lowest Upper Jurassic, Haifanggou Formation (ca. 161-162 Ma); Ningcheng County, Inner Mongolia, NE China.

Diagnosis: As for the genus. Six secondary antenodal crossveins between ScP and RA distal of $\mathrm{Ax} 2$; in forewing 10 postnodal crossveins between $\mathrm{C}$ and $\mathrm{RA}$ not aligned with 10 postsubnodal cross-veins between RA and RP1 basal of pterostigma.

Description: a fragment of thorax, with two forewings and one hindwing connected.

Forewing hyaline; $30.8 \mathrm{~mm}$ long, $6.0 \mathrm{~mm}$ wide; distance between base and arculus $4.0 \mathrm{~mm}$, arculus and nodus $10.0 \mathrm{~mm}$, nodus and pterostigma $12.4 \mathrm{~mm}$, pterostigma and apex $3.2 \mathrm{~mm}$; a short petiole $1.6 \mathrm{~mm}$ long, $1.0 \mathrm{~mm}$ wide; one row of cells between posterior wing margin and $\mathrm{AA}$; AA parallel to $\mathrm{MP}+\mathrm{Cu}$; median and submedian areas free; a curved strong vein $\mathrm{CuP}$ between submedian and subdiscoidal areas, lying well basal of arculus; subdiscoidal space free of crossveins, rather transverse; discoidal space basally opened; RP+MA separated at nearly a 
right angle from RA in arculus, strongly curved; RP separated from MA $0.1 \mathrm{~mm}$ distally; RP and MA well parallel; MAb rather short, ca. $0.6 \mathrm{~mm}$ long, well aligned with distal free part of $\mathrm{CuA}$; $\mathrm{CuA}$ separates from MP ca. $5.0 \mathrm{~mm}$ from wing base and directed towards posterior wing margin for $0.2 \mathrm{~mm}$; distal free part of $\mathrm{CuA}$ strong, $\mathrm{CuA}$ distally fused with $\mathrm{AA}$; $\mathrm{CuA}$ divided into a very short $\mathrm{CuAb}$ directed towards posterior wing margin and $\mathrm{CuAa}$ basally more or less parallel to posterior wing margin and distally delimitating a short and narrow cubito-anal area, with 1-2 posterior branches and 1-2 rows of cells at its broadest part; apex of CuA $1.5 \mathrm{~mm}$ basal of nodus level; area between $\mathrm{CuA}$ and MP with one row of cells; distal of apex of CuA, area between MP and posterior wing margin very long and broad; MP nearly straight, reaching posterior wing margin well distal of nodus level; MAa more or less parallel with MP, nearly straight in basal half but slightly zigzags distal of subnodus level; postdiscoidal area with one row of cells, $1.0 \mathrm{~mm}$ wide near discoidal cell and $0.8 \mathrm{~mm}$ at apex of MAa; Ax0 well-preserved very close to wing base; Ax1 $0.6 \mathrm{~mm}$ basal of arculus, nearly perpendicular to $\mathrm{ScP}$ and $\mathrm{R}+\mathrm{MA}$, Ax2 well distal of arculus, also perpendicular to ScP and RA, $2.6 \mathrm{~mm}$ distal of Ax1; no secondary antenodal crossveins between $\mathrm{C}$ and $\mathrm{ScP}$; six visible secondary antenodal crossveins between ScP and RA distal of Ax2; 10 postnodal crossveins between $\mathrm{C}$ and RA not aligned with 10 postsubnodal cross-veins between RA and RP1 basal of pterostigma; seven preserved crossveins in area between RA and RP, between arculus and nodus; base of RP3/4 $3.0 \mathrm{~mm}$ distal of arculus, closer to arculus than to nodus; base of IR2 close to that of RP3/4, $0.5 \mathrm{~mm}$ distally; no visible antefurcal crossvein in space between RP and MA basal of midfork (base of RP3/4); subnodus oblique and well aligned with nodal crossvein Cr; RP2 three cells distal of subnodus; Bqr space between RP, RP2, IR2 and oblique vein "O" long and narrow, with one row of cells and six cross-veins; oblique vein "O" nearly perpendicular to RP2 and IR2, one cell distal of RP2 base; RP2 nearly straight in its preserved part; base of IR1 four cells distal of base of RP2; IR1 basally straight and distally curved, more or less parallel to RP1, with one 
row of cells between them till the apex of pterostigma; area between MA and RP3/4 much widened distally, with several long intercalary longitudinal veins; area between RP3/4 and IR2 widened distally with an intercalary longitudinal vein zigzagging between them; area between IR2 and RP2 very narrow, without any intercalary longitudinal vein between them; pterostigma $2.0 \mathrm{~mm}$ long, $0.6 \mathrm{~mm}$ wide, covering two cells; pterostigmal brace neither aligned with basal side of pterostigma or strongly oblique.

Hindwing hyaline; distinctly shorter than forewing, $26.0 \mathrm{~mm}$ long, $5.6 \mathrm{~mm}$ wide, widest part at level of nodus; distance between base and arculus ca. $2.5 \mathrm{~mm}$ (arculus not preserved), between arculus and nodus ca. $7.9 \mathrm{~mm}$, nodus and pterostigma $10.3 \mathrm{~mm}$, pterostigma and apex $3.2 \mathrm{~mm}$; a very short petiole, $0.8 \mathrm{~mm}$ long, $0.5 \mathrm{~mm}$ wide; anal area not visible, but probably very narrow and triangular in shape, with one row of irregular cells between AA and AP; no anal angle (female specimen); no membranule; AA distally bent towards posterior wing margin and nearly parallel with $\mathrm{MP}+\mathrm{CuA}$, distally fused with $\mathrm{CuAb}$; median and submedian areas and vein $\mathrm{CuP}$ not visible; subdiscoidal area rather transverse, posteriorly closed, short and broad, with one basal crossvein, $1.2 \mathrm{~mm}$ long, $0.6 \mathrm{~mm}$ wide; discoidal cell basally closed, $1.0 \mathrm{~mm}$ long, $0.6 \mathrm{~mm}$ wide, free of crossveins, length of proximal side, ca. MA divided into MAa and MAb ca. 1.1 $\mathrm{mm}$ distal of arculus; MAb short, $0.6 \mathrm{~mm}$ long, aligned with distal free part of $\mathrm{CuA}$; $\mathrm{MP}+\mathrm{CuA}$ separated into MP and $\mathrm{CuA}$ at distal end of $\mathrm{MAb}$; distal free part of $\mathrm{CuA}$ strong, separates from MP $4.4 \mathrm{~mm}$ from wing base and extends towards posterior wing margin for $0.5 \mathrm{~mm}$; $\mathrm{CuA}$ distally divided into $\mathrm{CuAa}$ and $\mathrm{CuAb}, \mathrm{CuAb}$ short, $0.4 \mathrm{~mm}$ long, extends towards basal wing margin and meets main branch of AA; CuAa basally more or less parallel to posterior wing margin with 1-2 rows of cells between them; CuAa short, ending on posterior wing margin about $5.3 \mathrm{~mm}$ from its base; area between $\mathrm{CuAa}$ and $\mathrm{MP}$ with one row of cells, $0.5 \mathrm{~mm}$ wide; distal of end of $\mathrm{CuAa}$, area between MP and posterior wing margin very long and broad; MP nearly straight, reaching posterior margin well distal of nodus level, $16.0 \mathrm{~mm}$ from wing base; 
MAa parallel with MP, nearly straight in its basal part and weakly zigzagging distal of level of nodus, postdiscoidal area $0.5 \mathrm{~mm}$ wide, narrower near posterior wing margin, with one row of cells; Ax1 not visible; Ax2 $1.3 \mathrm{~mm}$ distal of arculus, nearly perpendicular to ScP; no secondary antenodal crossveins between $\mathrm{C}$ and $\mathrm{ScP}$, but five secondary antenodal crossveins between $\mathrm{ScP}$ and RA distal of Ax2; eight crossveins in area between RA and RP, between arculus and nodus; base of RP3/4 $2.1 \mathrm{~mm}$ distal of arculus, closer to arculus than to nodus; base of IR2 close to that of RP3/4, $0.6 \mathrm{~mm}$ distally; no visible antefurcal crossvein in space between RP and MA basal of midfork (base of RP3/4); nodal structures identical to those of forewing; nine postnodal crossveins between $\mathrm{C}$ and RA; eight postsubnodal crossveins between RA and RP1 not aligned with postnodals; pterostigmal brace rudimentary, not aligned with basal side of pterostigma; one crossvein below pterostigma; pterostigma sclerotized, $2.4 \mathrm{~mm}$ long, $0.5 \mathrm{~mm}$ wide; RP2 one cell distal of subnodus; four crossveins in Bqr space between RP, RP2, IR2 and oblique vein "O"; oblique vein "O" $2.4 \mathrm{~mm}$ and four cells distal of base of RP2; RP2 nearly straight; base of IR1 four cells distal of base of RP2; IR1 basally straight and distally curved, more or less parallel to RP1; area between MA and RP3/4 much wider distally, with 15 rows of cells along posterior wing margin; area between RP3/4 and IR2 slightly broader distally than basally, with basally one row of cells and four distally; area between IR2 and RP2 with one row of cells and distally six rows near posterior wing margin; area between RP2 and IR1 progressively widens, with two zigzagging intercalary longitudinal veins and four rows of cells between them; area between IR1 and RP1 not distally widen, with 2-3 rows of cells between them.

Remarks: Parazygokaratawia nov. gen. has nearly all the characters listed in the diagnosis of Zygokaratawia, i.e. hindwing subdiscoidal space small and posteriorly closed; cubito-anal and anal areas very narrow in both fore and hind wings (synapomorphy); a long basal part to $\mathrm{CuA}$ before its branches; area between MP and $\mathrm{CuA}$ as broad as postdiscoidal area, which is distally constricted; MP straight; MAa zigzags and becomes much weakened distally; CuAa short; 
pterostigma not basally recessed (Nel et al., 2008). Thus it is probably closely related to this genus in the family Karatawiidae, with which it also shares the putative synapomorphy 'space between MAa and MP distally constricted by an opposite curvature of these two veins'.

Parazygokaratawia and Zygokaratawia differ from all or nearly all Isophlebioidea in the very narrow fore- and hindwing cubito-anal and anal areas (Nel et al., 1993, 2007; Pritykina, 2006, etc.). But information on these structures is lacking for some genera. Adelophlebia Pritykina, 1980 is based only on a forewing base; it differs from Parazygokaratawia and Zygokaratawia in the presence of two rows of cells between CuAa and MP (Pritykina, 1980). The forewings of Parazygokaratawia and Zygokaratawia are rather similar to that of Karatawia Martynov, 1925, with an important difference in that the $\mathrm{CuA}$ is longer and better defined distally, and also the hindwings of Karatawia have distinctly broader cubito-anal areas (Li et al., 2012). Sarytashia Pritykina, 1970 is based on the apical half of a wing. It differs from Parazygokaratawia and Zygokaratawia in that its pterostigma is distinctly basally recessed (Pritykina, 1970).

Nevertheless, Parazygokaratawia has no distinct constriction in the area between RP3/4 and IR2 in all wings, unlike Zygokaratawia. On the contrary the area between these veins is rather widened along posterior wing margin in Parazygokaratawia. Parazygokaratawia also differs from Zygokaratawia in the base of RP2 not aligned with subnodus, IR1 basally straight, only one row of cells between IR1 and RP1 between its base and pterostigma, Ax2 perpendicular to ScP in hindwing, different number of antenodal, postnodal and antesubnodal crossveins. This set of characters is sufficient for an attribution to a different, new genus.

\section{Conclusion}

Parazygokaratawia comes from a higher layer of the same paleolake than the two Zygokaratawia species. Maybe it corresponds to a rather rapid local evolution within the same 
lineage, but this is delicate to show without a complete fossil record through all the strata of this outcrop. These two new discoveries show that the Campterophlebiidae with narrow wings are more diverse than previously supposed, even if they remain restricted to the Haifanggou Formation, in a palaeoenvironment of a high mountain lake (Huang, 2015).

\section{Acknowledgements}

We sincerely thank thre anonymous referees for their very useful comments on the first version of the paper. We are grateful to Li X-R for photography. This work was funded by the Ministry of Science and Technology (2016YFC0600406), the Strategic Priority Research Program of the Chinese Academy of Sciences (XDB18000000), the program Macroevolutionary Processes and Palaeoenvironments of Major Historical Biota (XDPB05) of the Chinese Academy of Sciences, and the National Natural Science Foundation of China (41688103 and 91514302). This study is a contribution to UNESCO-IUGS IGCP Project 632.

\section{References}

1. Bechly, G., 1996. Morphologische Untersuchungen am Flügelgeäder der rezenten Libellen und deren Stammgruppenvertreter (Insecta; Pterygota; Odonata), unter besonderer Berücksichtigung der Phylogenetischen Systematik und des Grundplanes der Odonata. Petalura, Böblingen, Special Volume 2, 402 pp.

2. Fabricius, J.C., 1793. Entomologia systematica emendata et aucta, secundum classes, ordines, genera, species, adjectis synonymis, locis, observationibus, descriptionibus. C.G. Proft, Hafniae, 3, 1-488.

3. Handlirsch, A., 1906-1908. Die fossilen Insekten und die Phylogenie der rezenten Formen. Ein Handbuch für Paläontologen und Zoologen. V.W. Engelman, Leipzig, v. 1430, p. (published in parts between 1906 and 1908 as follows: p. i-vi, 1-160, pls. 1-9 
(May 1906); p. 161-320, pls. 10-18 (June 1906); p. 321-480, pls. 19-27 (August 1906); p. 481-640, pls. 28-36 (October 1906); p. 641-800, pls. 37-45 (February 1907); p. 801960, pls. 46-51 (June 1907); p. 961-1120 (November 1907); p. 1121-1280 (January 1908); p. vii-ix, 1281-1430 (July 1908). Dated from publication information given on p. ix.).

4. Handlirsch, A., 1920. Geschichte, Literatur, Technik, Palaeontologie, Phylogenie, Systematik. Pp. 117-306 in C. Schröder (ed.) Handbuch der Entomologie. Vol. 3. Gustav Fisher, Jena.

5. Huang, D.-Y. 2015. Yanliao biota and Yanshan movement. Acta Palaeontologica Sinica $54,501-546$.

6. Li, Y.-J., Nel, A., Ren, D., Pang, H., 2012. Reassessment of the Jurassic damseldragonfly genus Karatawia (Odonata: Campterophlebiidae). Zootaxa 3417, 64-68.

7. Martynov, A.V., 1925. To the knowledge of fossil insects from Jurassic beds in Turkestan. Izvestiya Akademii Nauk 17, 569-598.

8. Nel, A., Huang, D.-Y., Lin, Q.-B., 2007. A new genus of isophlebioid damseldragonflies (Odonata: Isophlebioptera: Campterophlebiidae) from the Middle Jurassic of China. Zootaxa 1642, 13-22.

9. Nel, A., Huang, D.-Y., Lin, Q.-B., 2008. A new genus of isophlebioid damseldragonflies with "calopterygid"-like wing shape from the Middle Jurassic of China (Odonata: Isophlebioidea: Campterophlebiidae). European Journal of Entomology 105, $783-787$.

10. Nel, A., Martínez-Delclòs, X., Paicheler, J.-C., Henrotay, M., 1993. Les ‘Anisozygoptera' fossiles. Phylogénie et classification (Odonata). Martinia Numéro Hors Série 3, 1-311. 
11. Petrulevičius, J.F., Huang, D.-Y., Nel, A., 2011. A new genus and species of damseldragonfly (Odonata: Isophlebioidea: Campterophlebiidae) in the Middle Jurassic of Inner Mongolia, China. Acta Geologica Sinica (English Edition) 85, 733-738.

12. Pritykina, L.N., 1970. Triassic and Jurassic dragonflies of the Liassophlebiidae from Soviet Central Asia. Paleontological Journal 4, 91-102.

13. Pritykina, L.N., 1980. [New fossil Odonata from the Mesozoic of Central Asia.] pp. 119-131. In: Dolin, V.G., Panfilov, D.V., Ponomarenko, A.G., Pritykina, L.N. [Mesozoic fossil insects.] Naukova Dumka, Kiev, 1-134. [In Russian.]

14. Pritykina, L.N., 2006. Isophlebiid dragonflies from the Late Mesozoic of Eastern Transbaikalia (Odonata: Isophlebiidae). Paleontological Journal 40, 636-645.

15. Riek, E.F., Kukalová-Peck, J., 1984. A new interpretation of dragonfly wing venation based upon Early Carboniferous fossils from Argentina (Insecta: Odonatoidea) and basic characters states in pterygote wings. Canadian Journal of Zoology 62, 1150-1166.

16. Zheng, D.-R., Nel, A., Wang, B., Jarzembowski, E.A., Chang, S.-C., Zhang, H.-C. 2016. A new damsel-dragonfly from the Lower Jurassic of northwestern China and its paleobiogeographic significance. Journal of Paleontology 90, 485-490.

17. Zheng, D.-R., Dong, C., Wang, H., Ye, Y.-F., Wang, B., Chang, S.-C., Zhang, H.-C. 2017. The first damsel-dragonfly (Odonata: Isophlebioidea: Campterophlebiidae) from the Middle Jurassic of Shaanxi Province, northwestern China. Alcheringa: An Australasian Journal of Palaeontology 41, 509-513.

Fig. 1. Log and map of fossil localities. a, Daohugou beds divided by fossil Branchiopoda, blue arrow: layer with Zygokaratawia incompleta nov. sp., red arrow: layer with Parazygokaratawia azari nov. gen., nov. sp.; b, map showing the fossil localities near Daohugou village, blue spot: location for Zygokaratawia incompleta nov. sp.; c, map of the Daohugou fossil bed outcrops, 
blue spot: layer with Zygokaratawia incompleta nov. sp., red spot: layer with Parazygokaratawia azari nov. gen., nov. sp.

Fig. 2. Zygokaratawia incompleta nov. sp., holotype NIGP167276. a, complete habitus; b, right hindwing, dry; c, right hindwing, under alcohol. Scale bars: $1 \mathrm{~cm}$.

Fig. 3. Parazygokaratawia azari nov. gen., nov. sp., holotype NIGP167528. a, complete habitus; $\mathbf{b}$, left and right forewings, dry. Scale bars: $1 \mathrm{~cm}$.

Fig. 4. Parazygokaratawia azari nov. gen., nov. sp., holotype NIGP167528. Hindwing. Scale bar: $5 \mathrm{~mm}$. 


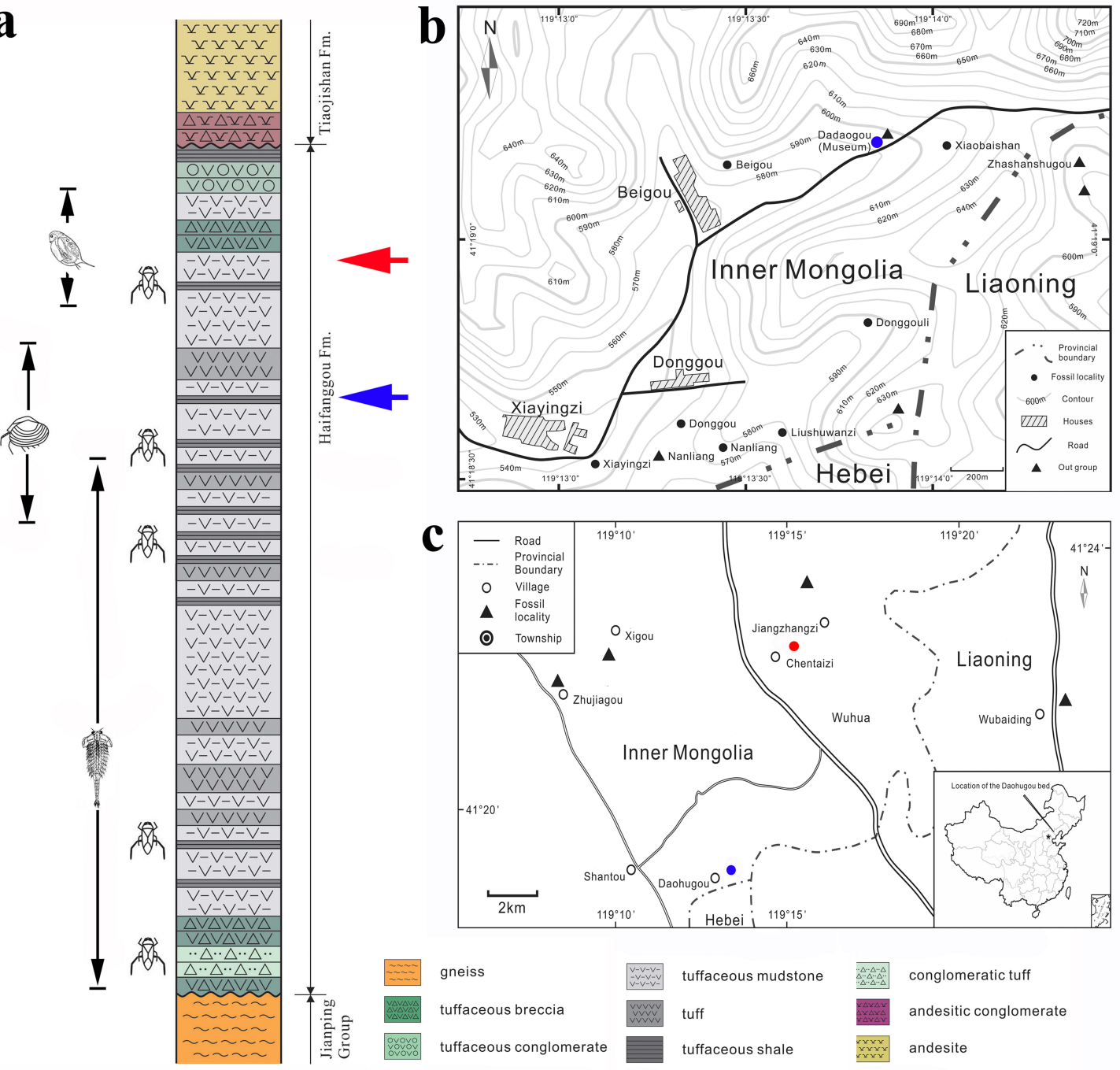


1.

2).

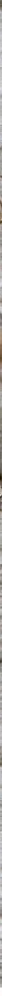

b

a $12=3$

(2) $-3,2=12-12$

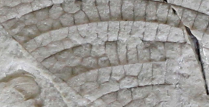

a.
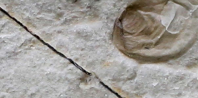

a sone $+x$
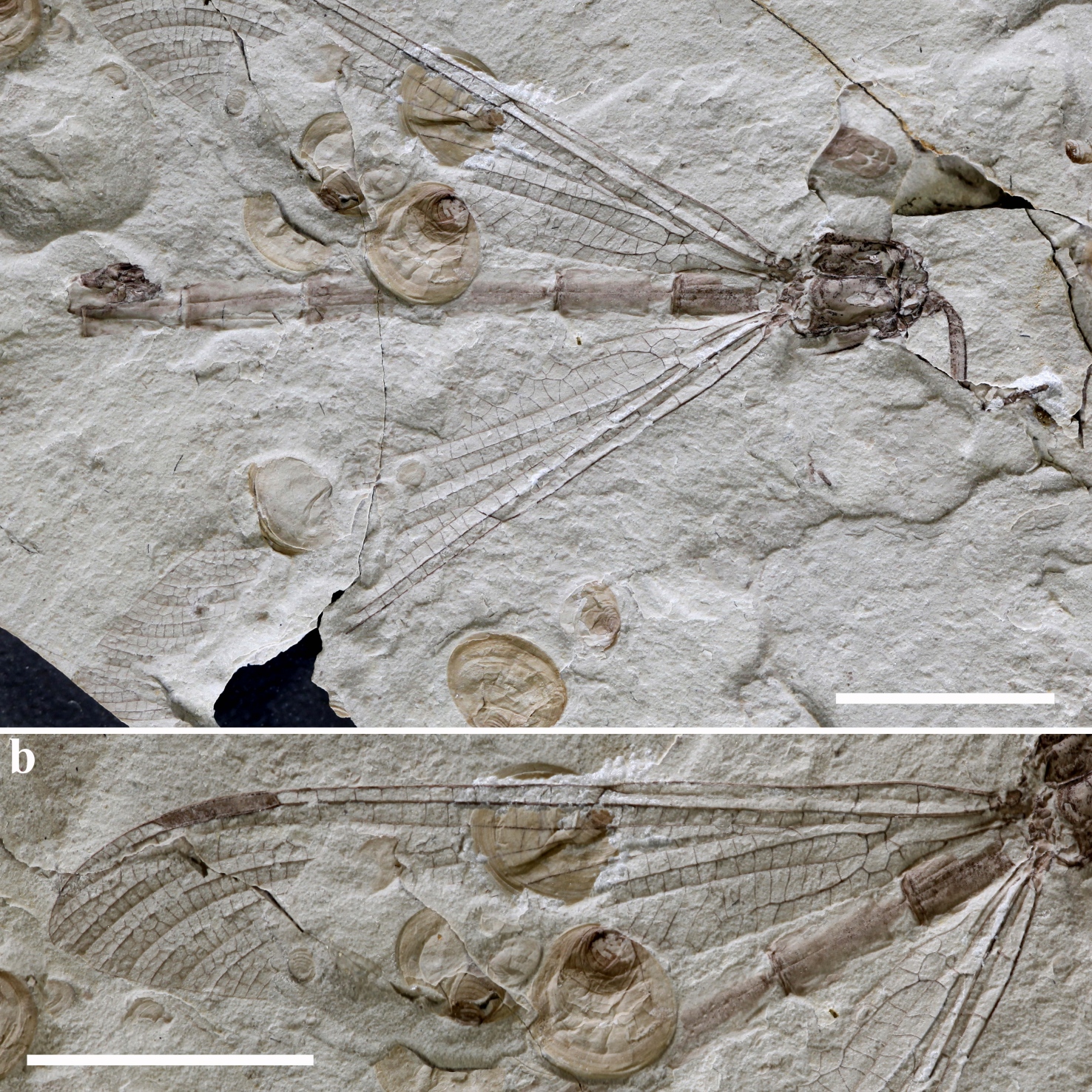

c

$\mathrm{Pt}$

N

1

in

$\int_{\mathrm{RP} 2}^{\mathrm{IR} 1-}$

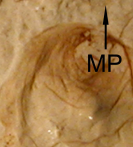

MP

$\mathrm{CuA}_{\mathrm{Cu}}$

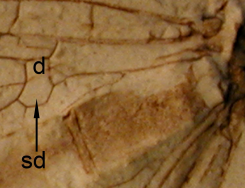


q

$=1$ $-\sqrt{1-\sqrt{2}}$

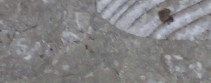

\section{b}

$x^{2}+x^{2}=$

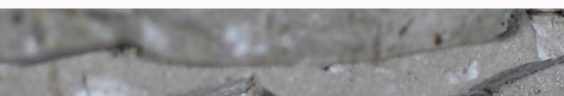

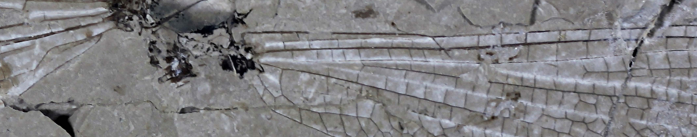
(x) $\quad(-2.14$

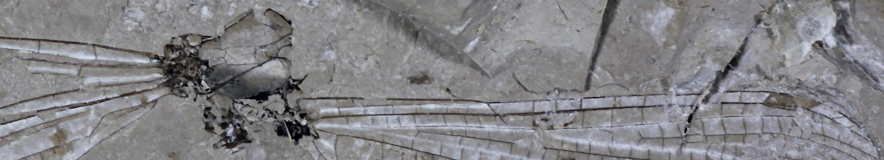

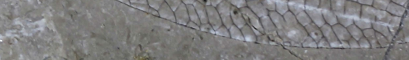
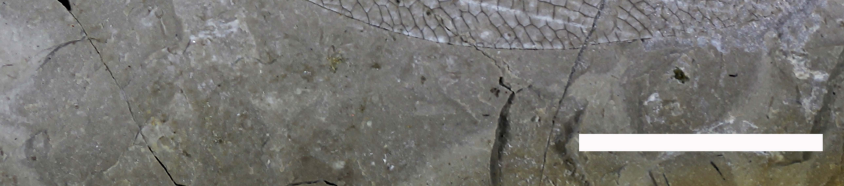

$\lim ^{2}$

25ints

- mentint
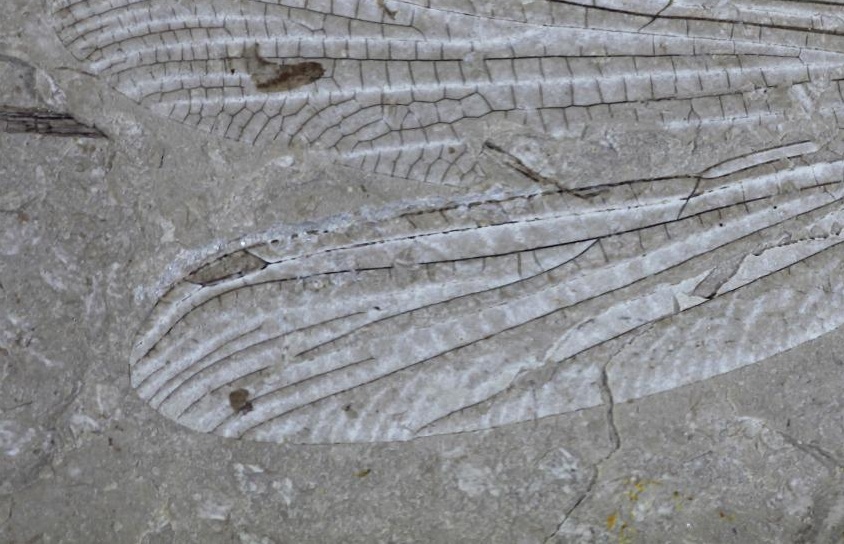

s.
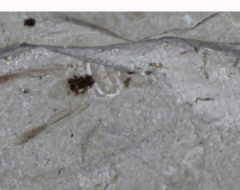

-

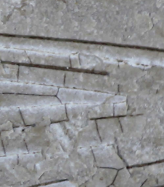

Ax
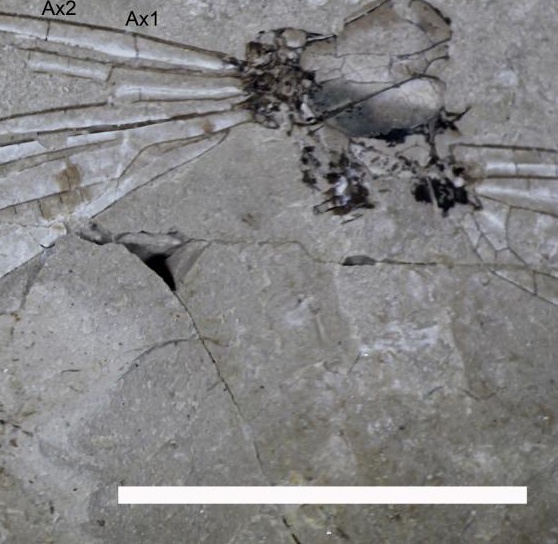


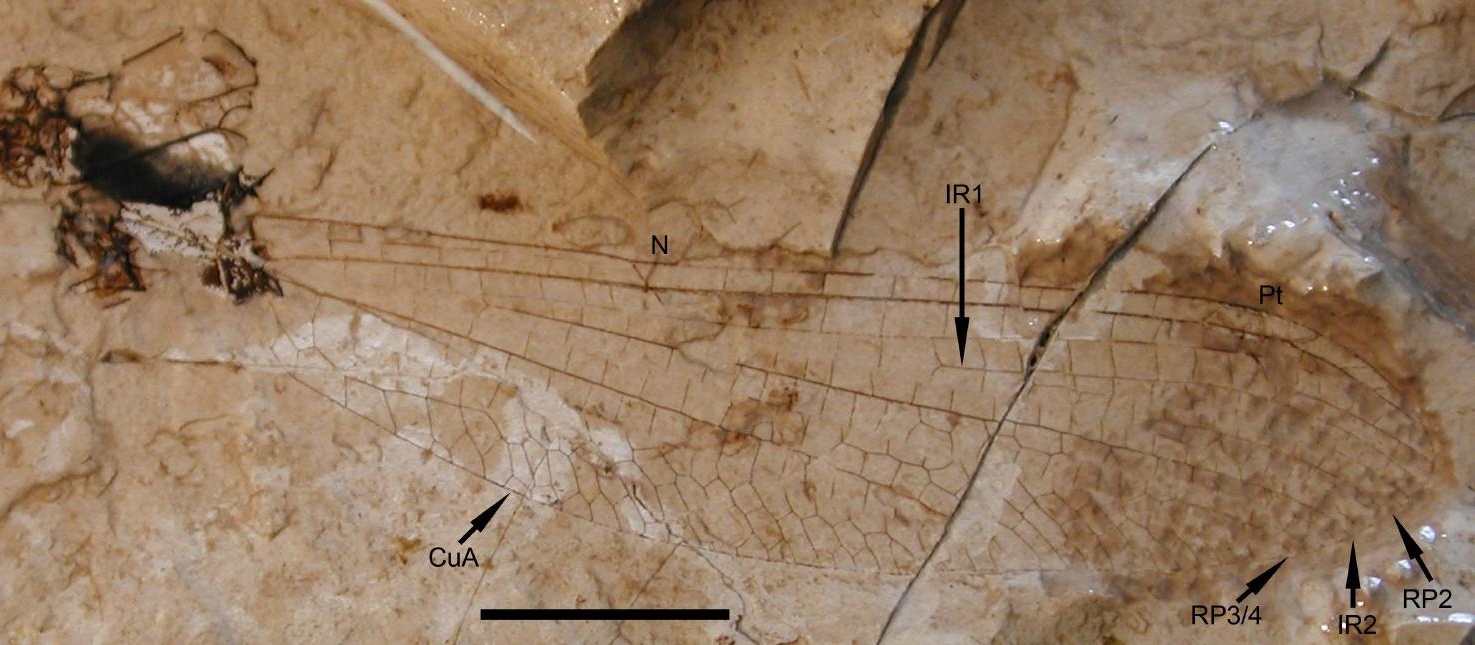

